DOI: $10.12731 / 2306-1561-2013-4-38$

\title{
REVIEW OF TRANSPORTATION TECHNOLOGIES CONCRETE MIXTURES ROAD
}

Bashmakov I.A., Polgun M.B., Jha Prabhakar, Ostroukh A.V.

\section{Abstract}

The article analyzes the existing transportation technology of concrete mixes for road transport, including the organization of preparatory operations for loading concrete for rolling stock and unloading it in the point of delivery. Conditions under which it is possible rationalization.

Keywords: transport, road transport, the concrete mix, concrete, technology, customer service, concrete mixing plant, concrete plant-solution, cement mixer.

\section{УДК 656.025}

\section{ОБЗОР ТЕХНОЛОГИЙ ТРАНСПОРТИРОВКИ БЕТОННЫХ СМЕСЕЙ АВТОМОБИЛЬНЫМ ТРАНСПОРТОМ}

\section{Башмаков И.А., Польгун М.Б., Джха Прабхакар, Остроух А.В.}

\begin{abstract}
Аннотация
B статье проведен анализ существующей технологии транспортировки бетонных смесей автомобильным транспортом, включая организацию подготовительных операций $\kappa$ погрузке бетонной смеси на подвижной состав $и$ разгрузке его в пункте доставки. Приведены условия, при которых возможна ее рационализачия.
\end{abstract}

Ключевые слова: транспортировка, автомобильный транспорт, бетонная смесь, товарный бетон, технология, обслуживание потребителей, бетоносмесительный завод, раствор-бетонный узел, автобетоносмеситель.

\section{Введение}

На сегодняшний день в России при производстве бетонных и железобетонных работ применяется общая, универсальная технология транспортирования бетонных смесей [1 - 14]. Она вариативна и зависит от характера проводимых работ, требуемого качества работ, установленных сроков проведения работ, общего объема работ, качественного и количественного состава применяемой строительной техники. 
В настоящее время, под технологией понимается - совокупность процессов, методов и конкретных материалов, используемых в определенной деятельности, а также строгое научное описание способов технического производства. В более узком смысле под технологией понимают комплекс конкретных организационных мер, этапов и операций, идущих последовательно и ограниченных заданными условиями их реализации.

Этап - перечень конкретных операций, с реализацией которых осуществляется технологический процесс.

Операция - логически целостная и однородная часть технологического процесса, направленная на достижение поставленной в данном процессе цели, выполняемая одним или несколькими исполнителями.

Подача бетонной смеси - перемещение бетонной смеси в пределах строящегося объекта до блока бетонирования.

Блок бетонирования - подготовленная к укладке бетонной смеси конструкция или ее часть со смонтированной арматурой и установленной опалубкой.

Распределение бетонной смеси - перемещение бетонной смеси в блоке бетонирования, для полного и равномерного его заполнения.

\section{Этапы технологии транспортировки бетонных смесей}

В частности, наиболее распространенная технология транспортировки бетонных смесей включает в себя приведенный ниже набор этапов и операций:

1) Погрузка бетонной смеси в транспортное средство на бетоносмесительном заводе:

- подача транспортного средства под погрузку;

- предоставление документального подтверждения соответствия фактического состава бетонной смеси, указанному в договоре на поставку;

- осуществление погрузки смеси в транспортное средство;

- выезд транспортного средства с территории бетоносмесительного завода.

2) Транспортировка бетонной смеси на строящийся объект:

- следование груженого транспортного средства по маршруту от бетоносмесительного завода, до строящегося объекта.

3) Выгрузка бетонной смеси из транспортного средства:

- прибытие транспортного средства к месту выгрузки бетонной смеси;

- осуществление выгрузки бетонной смеси.

4) Подача бетонной смеси в блок бетонирования:

- перемещение бетонной смеси с места выгрузки в блок бетонирования.

5) Распределение бетонной смеси в блоке бетонирования:

- равномерное перемещение бетонной смеси внутри блока бетонирования. 
Типовая схема бетоносмесительного завода выглядит, как показано на рисунке 1.

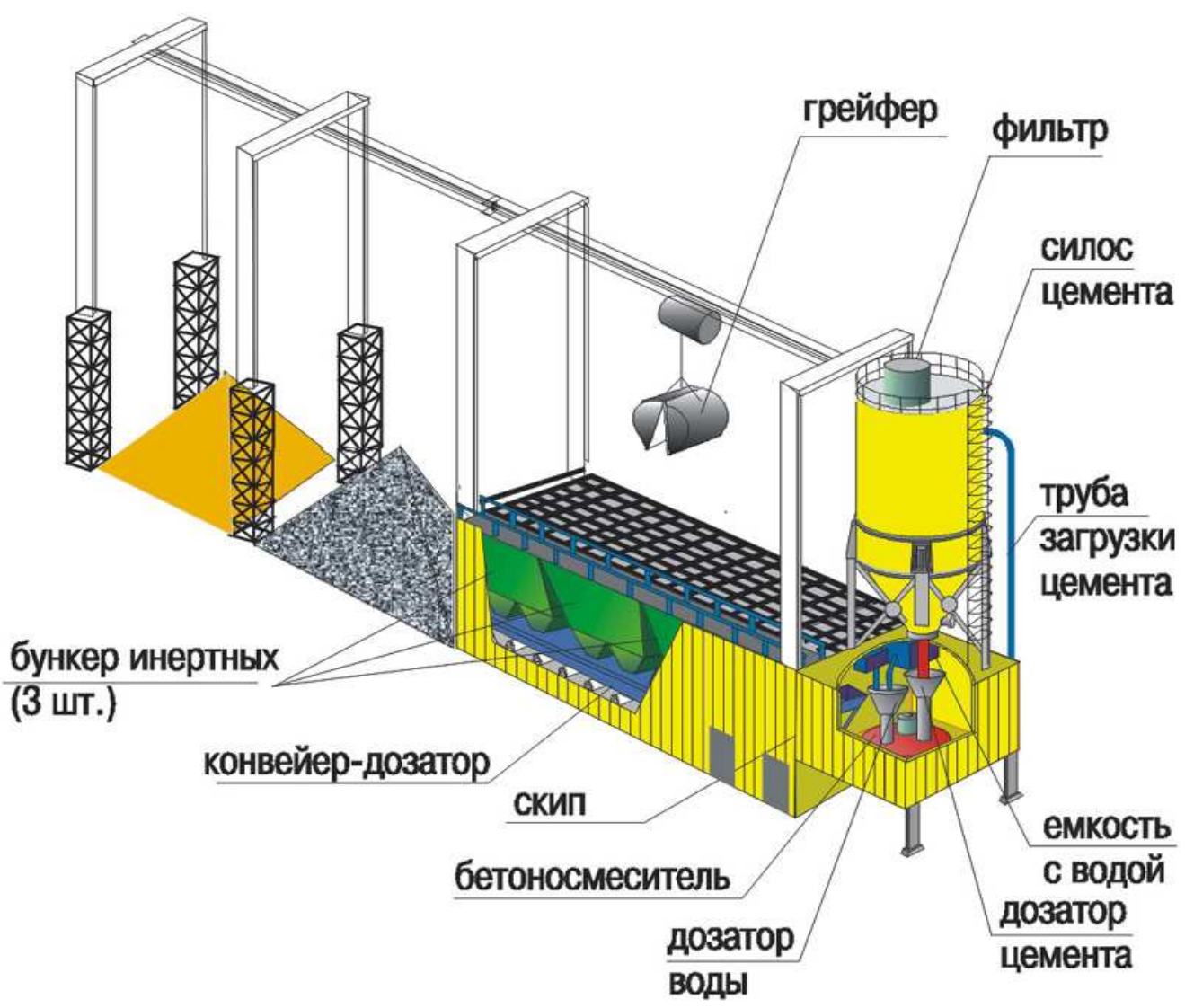

\section{Рисунок 1 - Типовая схема бетоносмесительного завода}

На схемах, представленных на рисунках 2, 3, наглядно показаны типичные комбинации этапов используемой технологии транспортирования бетонных смесей автомобильным транспортом.

Транспортировка товарных бетонных смесей на большие расстояния

При транспортировании товарных бетонных смесей на большие расстояния (до 10 км и более) применяют специализированные транспортные средства на базе грузовых автомобилей - автобетоносмесители (рисунок 4). Они оснащены специальным оборудованием для сохранения качеств бетонных смесей в пути следования, которое предохраняет их от попадания атмосферных осадков, солнечных лучей, не дает смеси расслаиваться (вытекать цементному молоку или раствору), зимой предохраняет ее от быстрого охлаждения и замерзания. 


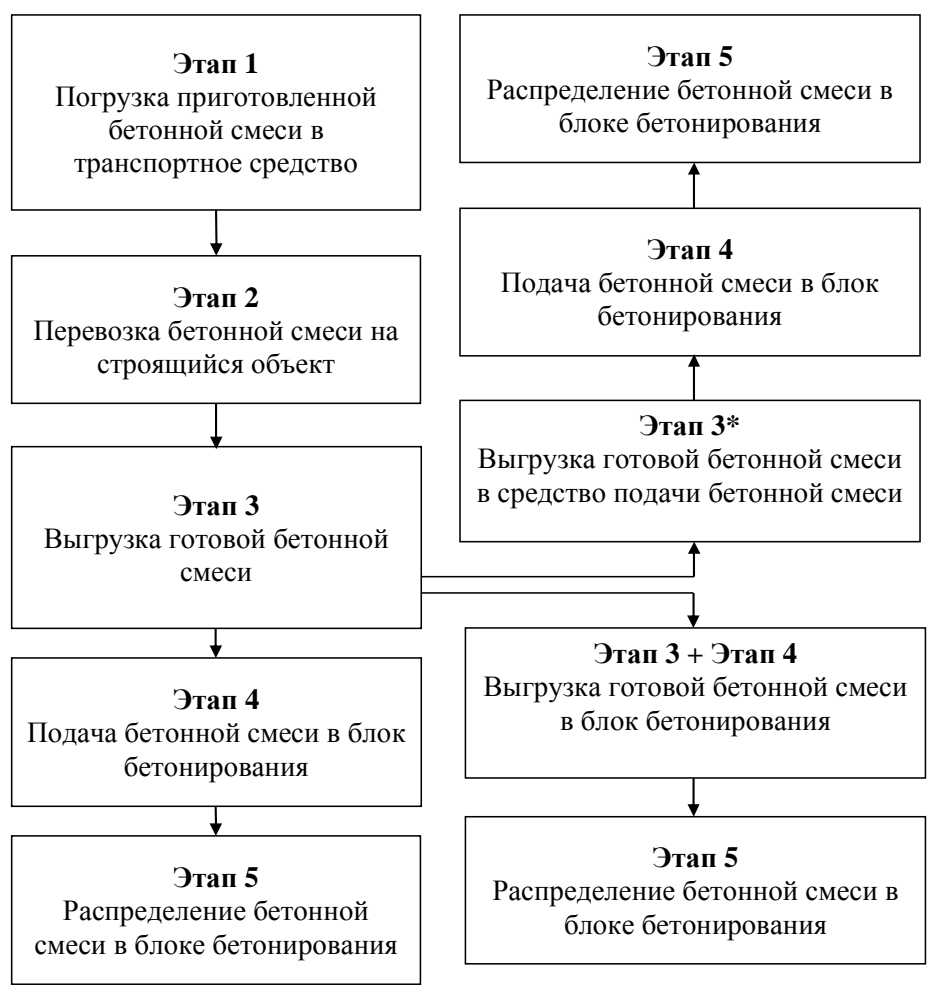

Рисунок 2 - Технологическая схема процесса транспортирования готовой бетонной смеси

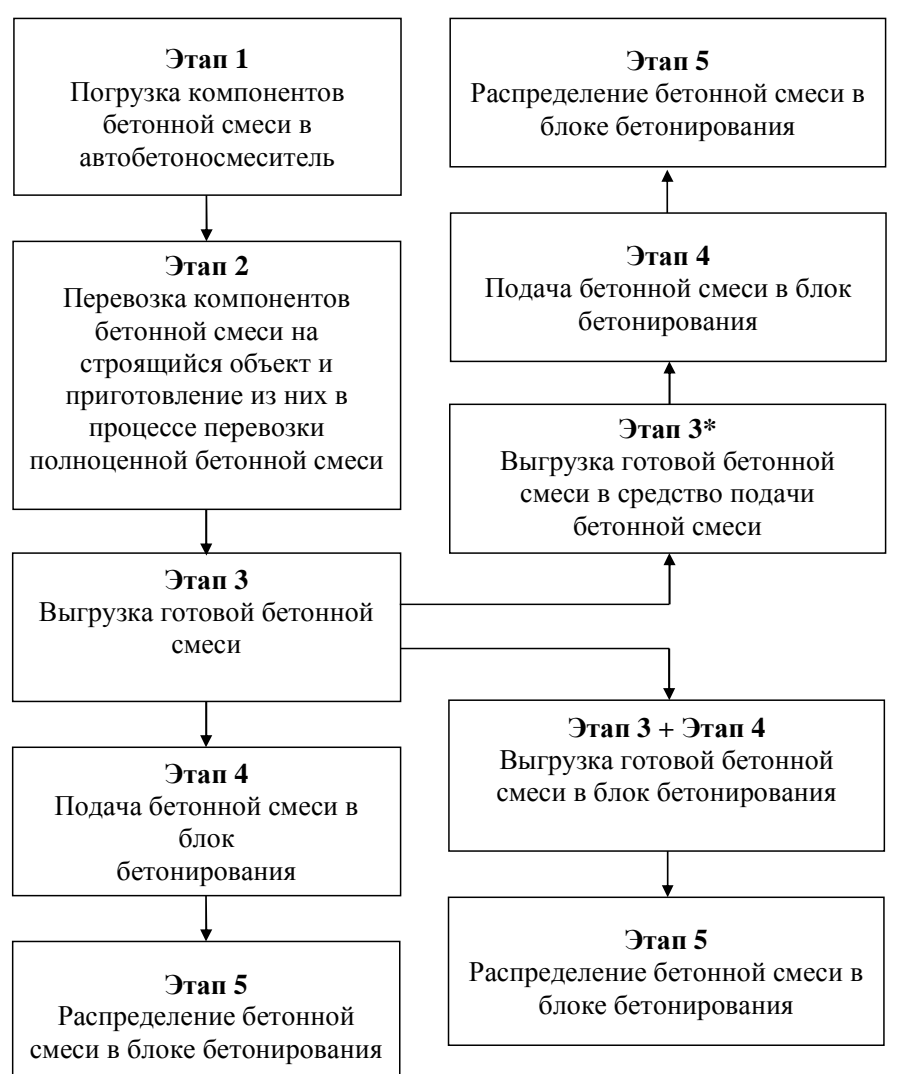

Рисунок 3 - Технологическая схема процесса транспортирования компонентов бетонной смеси с последующим ее приготовлением 


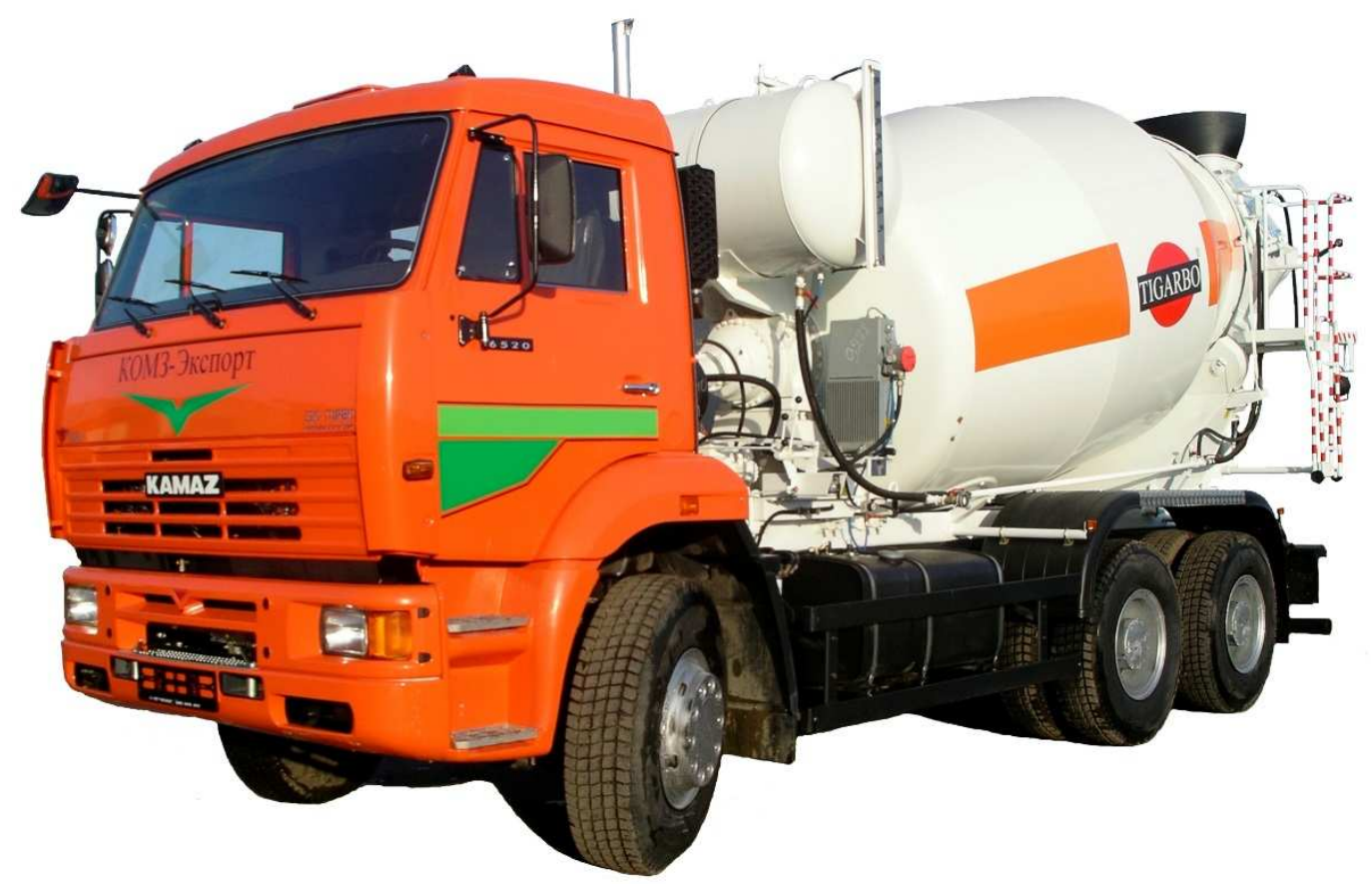

\section{Рисунок 4 - Автобетоносмеситель для транспортирования бетонных смесей}

Автобетоносмесители предназначены для быстрого транспортирования на значительные расстояния (около 35 - 40 км) готовых пластичных бетонных смесей, а также для приготовления бетонной смеси в пути следования или непосредственно на строящемся объекте. Автобетоносмеситель представляет собой шасси грузового автомобиля, на котором смонтированы смесительный барабан с загрузочноразгрузочным устройством, узлы привода барабана с механизмом управления, дозировочно-промывочный бак и водяной центробежный насос.

Для сохранения однородности готовой бетонной смеси в процессе транспортирования при использовании автобетоносмесителя в качестве бетоновоза, смесительный барабан медленно вращается (3 - 4 об/мин), непрерывно перемешивая смесь. Если необходимо, автобетоносмеситель может сам приготовить бетонную смесь, для этого сухие исходные материалы загружаются в смесительный барабан через загрузочную воронку загрузочно-разгрузочного устройства. К внутренней поверхности барабана прикреплены две винтовые лопасти. При вращении барабана по часовой стрелке компоненты смеси направляются в нижнюю часть барабана, где происходит их гравитационное перемешивание, а при вращении в обратную сторону лопасти подают готовую смесь к приемному лотку, соединенному с поворотным разгрузочным желобом. После разгрузки производится промывка барабана водой из дозировочнопромывочного бака.

Для приготовления бетонной смеси в пути следования водитель автобетоносмесителя за 5 - 10 мин до прибытия к месту выгрузки смеси включает привод смесительного барабана. Одновременно с началом вращения (9 - 14 об/мин) в барабан подаётся водяным насосом определенная порция воды из дозировочнопромывочного бака. 
Транспортировка товарных бетонных смесей в пределах строительной площадки

При транспортировании бетонных смесей в пределах строительной площадки часто применяется трубопроводный транспорт - бетононасосы и бетононагнетатели. Благодаря транспортированию по трубам, максимально сохраняется качество смеси и сводятся к минимуму её потери.

Бетононасосы (рисунок 5) применяют для непрерывного транспортирования готовой бетонной смеси, к месту укладки по металлическим трубам-бетоноводам на расстояния около 300 м по горизонтали или около 50 м по вертикали, при выполнении бетонных работ большого объема. Современные бетононасосы как правило монтируется на шасси автомобиля и представляет собой поршневую машину с механическим и гидравлическим приводом. Бетононасосы с механическим приводом выполняют одноцилиндровыми, с гидравлическим - двухцилиндровыми.

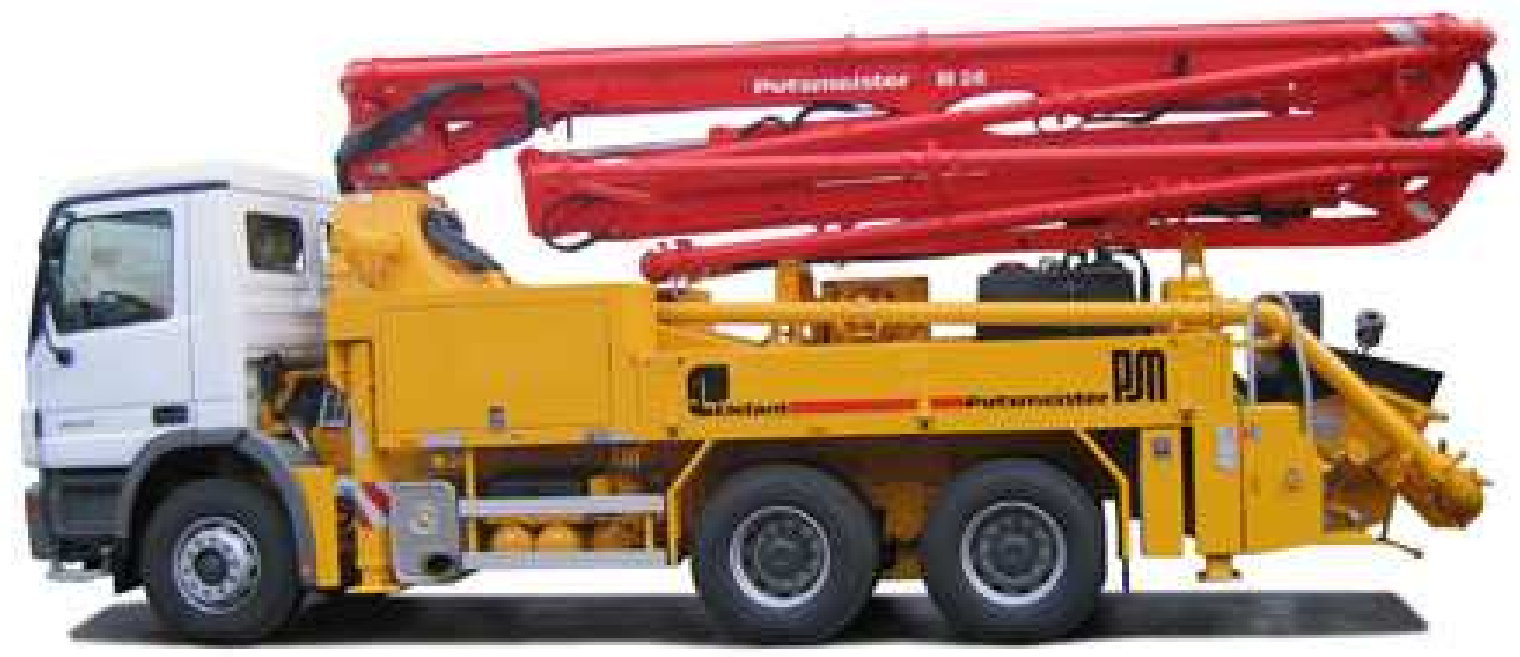

Рисунок 5 - Бетононасос, смонированный на шасси автомобиля

Типичный бетононасос состоит из распределительной стрелы, рамы, приемной воронки, распределительного устройства, опорных стоек, поворотного устройства, цилиндропоршневой группы, привода гидронасоса, компрессора, блока управления.

В последнее время получили также распространение комбинированные машины, которые сочетают в себе достоинства автобетононасоса и бетоносмесителя: они транспортируют и перемешивают бетон как обычные автобетоносмесители, а на стройплощадке обеспечивают подачу и распределение материала (рисунок 6). 


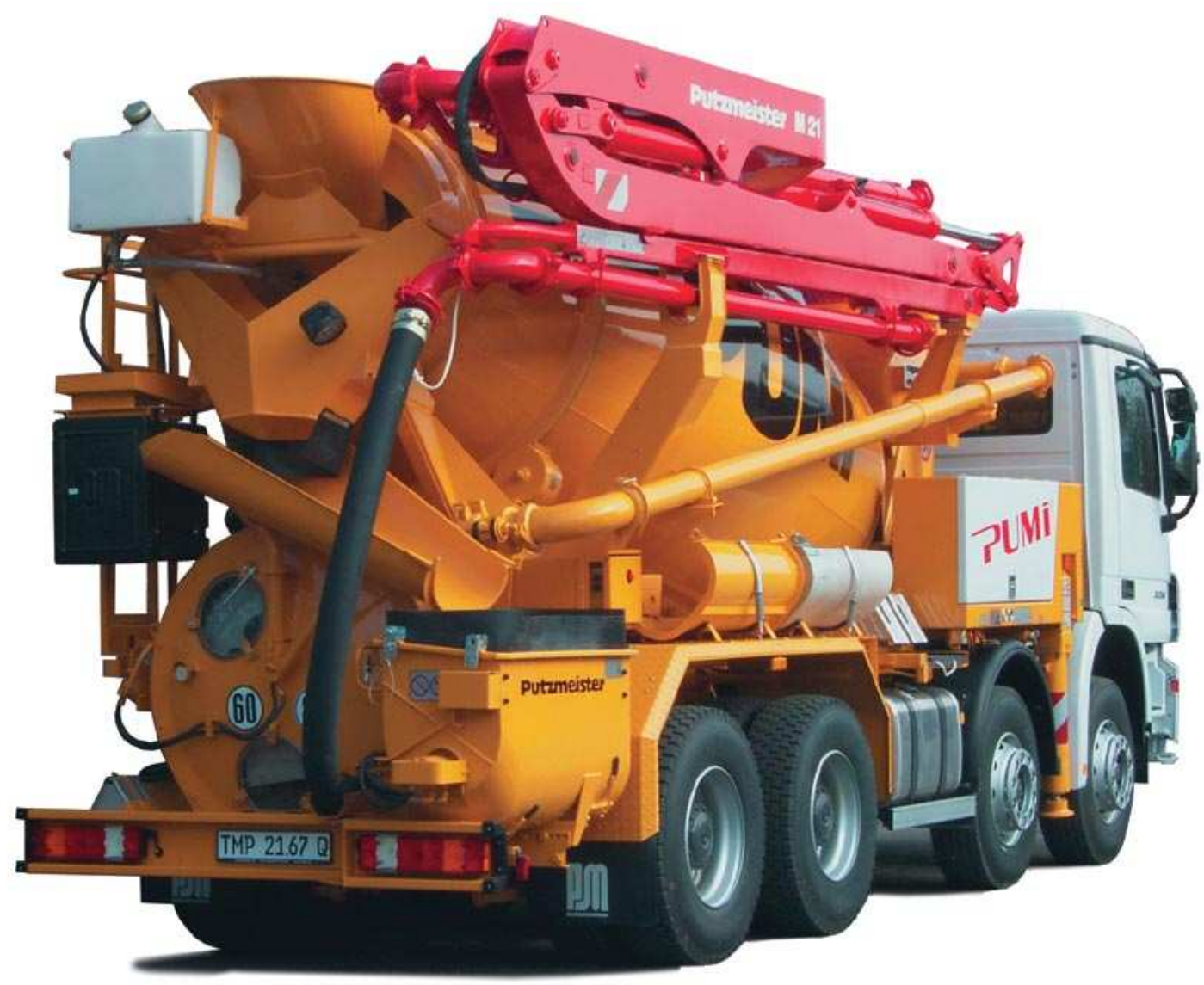

Рисунок 6 - Комбинированная машины (автобетононасос и бетоносмеситель)

Основыне преимущества такой машины:

- Использование одной машины вместо двух сокращает организационные затраты на строительном объекте.

- Машиной управляет один оператор.

- Машина обеспечивает рентабельность при работе на малых объектах, тем самым расширяется диапазон работ, выполняемых предприятием заказчика.

- Машина выполняет 4-5 поездок в день.

При строительстве железобетонных сооружений применяют также и пневматические бетононагнетатели (рисунок 7), использующие для транспортирования бетонной смеси по трубам энергию сжатого воздуха. 


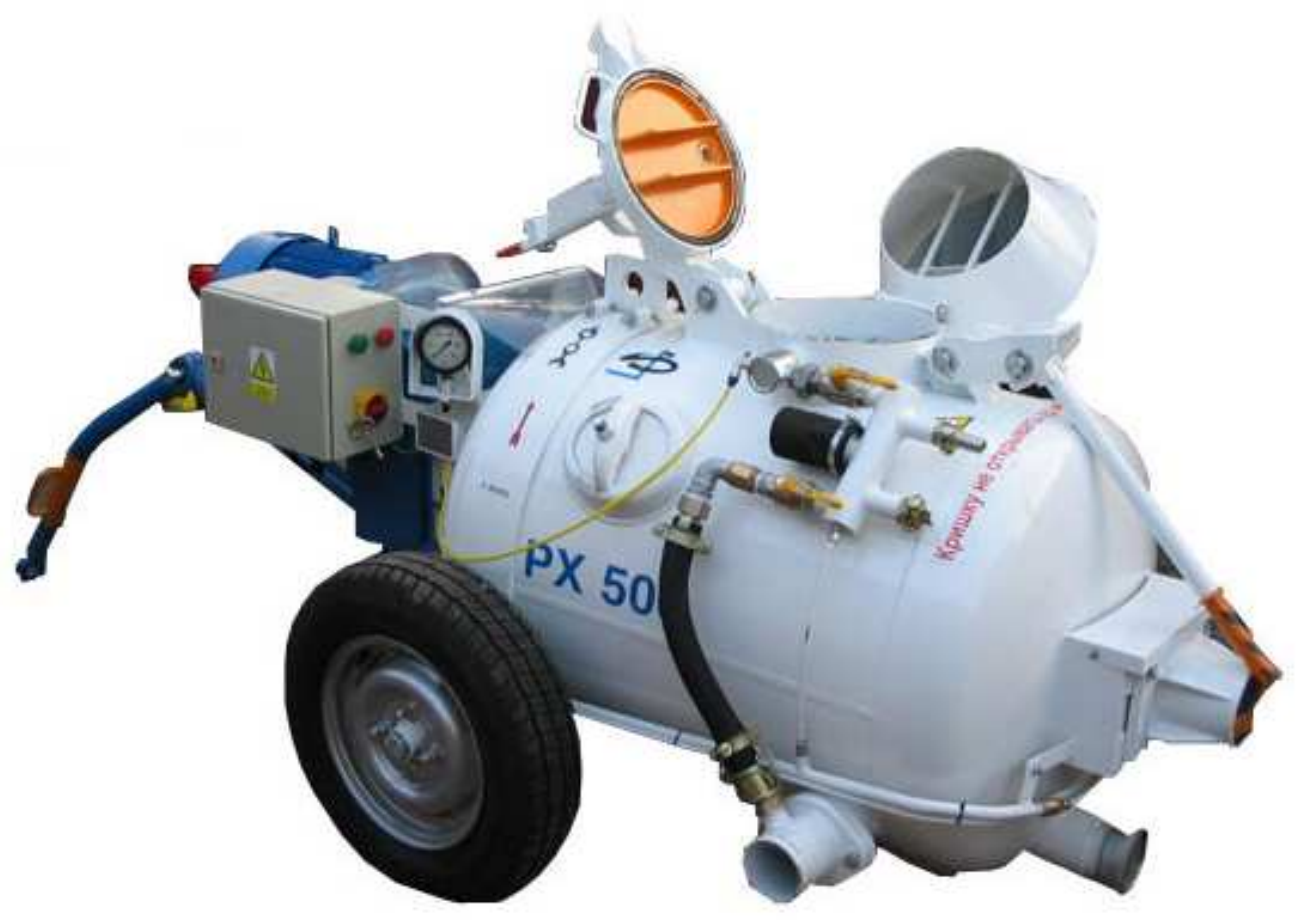

Рисунок 7 - Пневматический бетононагнетатель

Они состоят из компрессора, ресивера, выравнивающего рабочее давление в воздухораспределительной сети, нагнетателя, гасителя, бетоновода и системы управления.

\section{Транспортировка товарных бетонных смесей внутри строящегося объекта}

Транспортирование бетонной смеси внутри строящегося объекта может осуществляться также и кранами, с помощью строительных бадей, ленточными транспортерами, самоходными бетоноукладчиками, подъемниками, мототележками и виброжелобами с вибропитителями.

Самоходные, башенные и стреловые краны с комплектом бадей используют для порционной подачи и распределения бетонной смеси в блоках бетонирования. Доставленную автомобильным транспортом бетонную смесь разгружают на объекте в бадьи и кранами подают непосредственно в конструкцию.

Бадьи бывают поворотные и неповоротные (рисунок 8). Поворотная бадья представляет собой сварную емкость, состоящую из корпуса, каркаса, затвора, рычага.

Иногда на корпус бадьи устанавливают вибратор. Каркас выполнен в виде салазок, конструкция которых позволяет загружать бадью в горизонтальном положении.

При подъеме краном бадью стропуют за петли и она, плавно перекатываясь, занимает вертикальное положение. В таком положении бадья перемещается и разгружается. При опускании бадьи под загрузку она плавно принимает горизонтальное положение загрузочным отверстием кверху. 


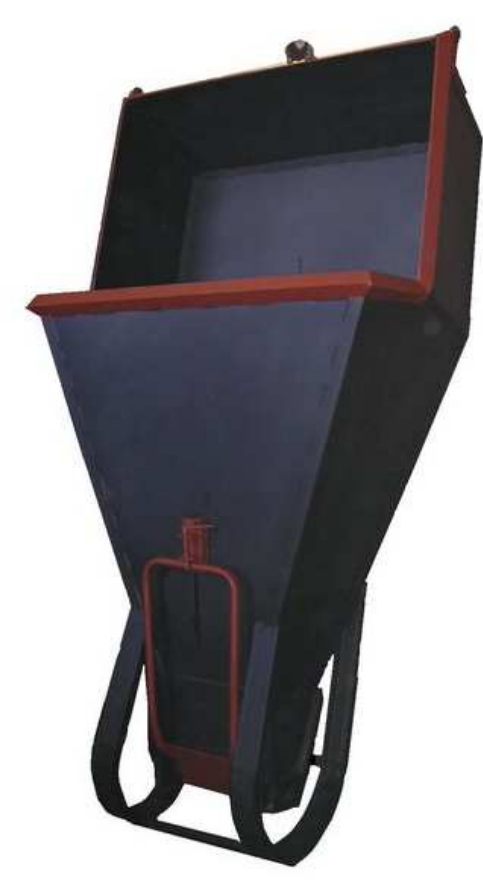

Поворотная бадья

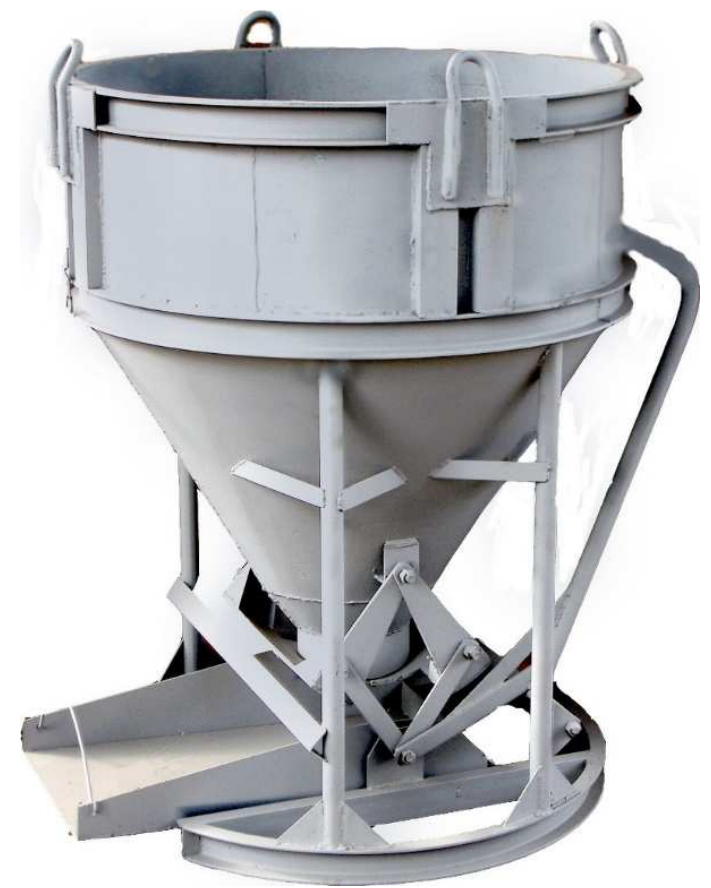

Неповоротная бадья

\section{Рисунок 8 - Бадьи для бетона}

Неповоротная бадья (см. рисунок 8) также представляет собой сварную емкость, но в отличии от поворотной, она подается под загрузку в вертикальном положении. Преимущественное применение имеют поворотные бадьи; неповоротные бадьи используют в тех случаях, когда бетонную смесь нужно подавать небольшими порциями (в колонны, стены небольшой толщины и др.). Бадьи обычно изготовляют вместимостью 0,5-2 $\mathrm{m}^{3}$.

В строительстве, ленточные, секционные и звеньевые конвейеры используют для подачи бетонной смеси в основном при бетонировании конструкций с небольшими размерами (точечные конструкции).

Для нужд строителей имеются ленточные конвейеры передвижного типа длиной 6-15 м и шириной гладкой или ребристой ленты 400-500 мм. Такие конвейеры могут подавать бетонную смесь на высоту 1,5-4 м.

Основным рабочим органом конвейера является гибкая прорезиненная лента, огибающая приводной и натяжной барабаны и опирающаяся на поддерживающие верхние роликовые опоры желобчатого типа и нижние плоские роликовые опоры. Бетонную смесь загружают на ленту через питатели, позволяющие непрерывно и равномерно подавать смесь требуемой толщины.

При большом объеме наземных работ по укладке бетона самыми производительными и удобными являются самоходные бетоноукладчики (рисунок 9). Они представляют собой самоходные машины, чаще всего на гусеничном ходу, оборудованные бетоноукладочным оборудованием. 


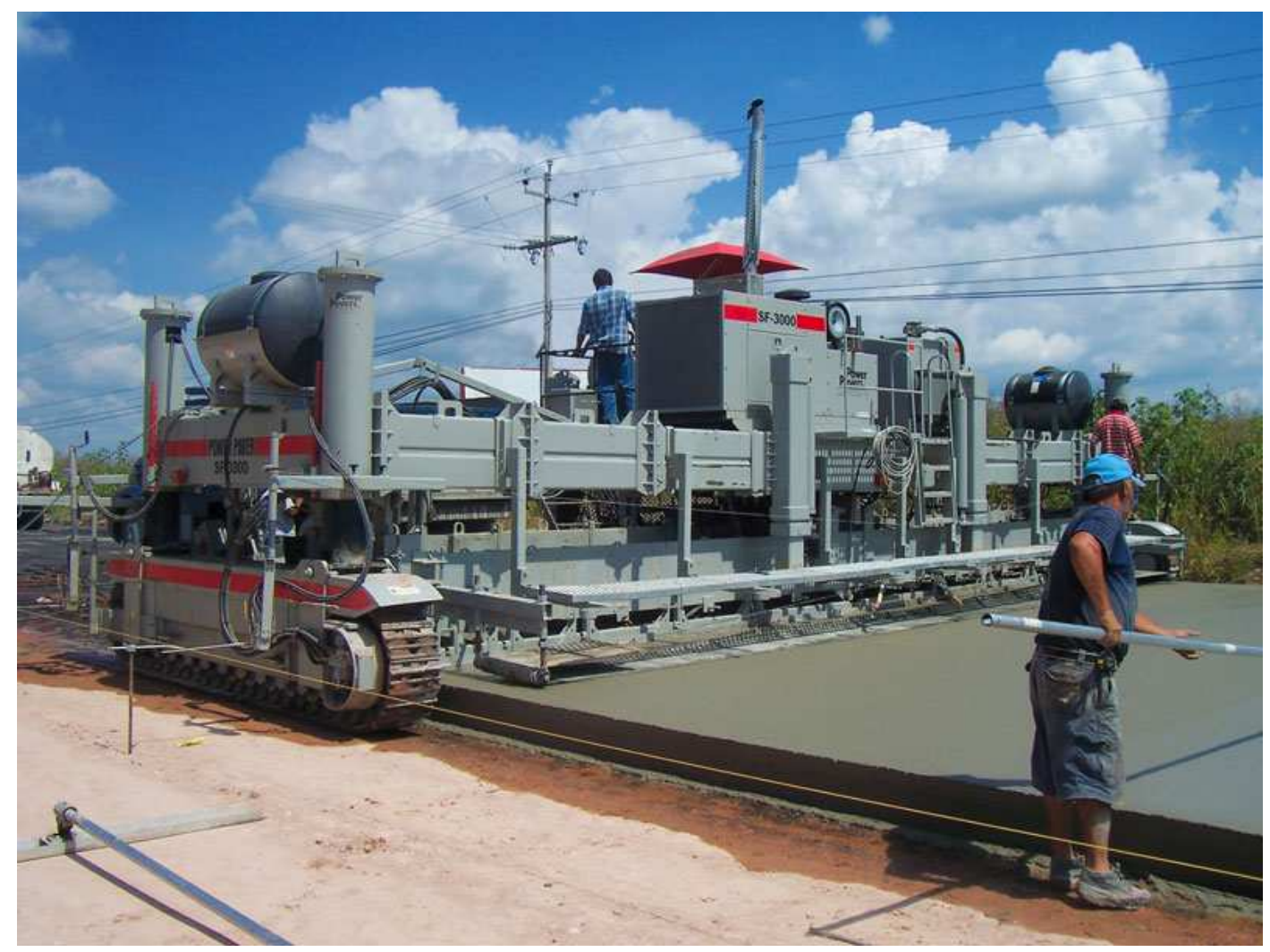

\section{Рисунок 9 - Самоходный бетоноукладчик}

При транспортировании бетонной смеси на строящемся объекте с этажа на этаж или с уровня земли в котлован, могут применяться различные по конструкции подъемники. Подъемники - это машины, предназначенные для подъема и спуска бетонной смеси с помощью смесенесущих устройств, перемещающихся по вертикальным или наклонным направляющим.

Мототележки используются для транспортирования малых порций бетонных смесей на строительной площадке. Они загружаются из накопительных и перегрузочных бункеров или приобъектного бетоносмесительного заводи, или растворного узла. В настоящее время мототележки используются только при крупном и специфичном строительстве (метрополитен, ГЭС и др.).

Транспортирование бетонной смеси в конструкции, расположенные в котловане (ниже уровня земли), осуществляют с промежуточной перегрузкой в вибропитатель и последующей подачей в блок бетонирования виброжелобами.

Вибропитатель представляет собой треугольный сварной ящик, оборудованный вибратором. Вибропитатель устанавливают так, чтобы днище его было наклонено на 5$10^{\circ}$ в сторону бетонируемой конструкции. Выходной проем вибропитателя оборудован секторным затвором. К выходному проему прикрепляют виброжелоба длиной 4 или 6 м. Благодаря такой конструкции, бетонные смеси могут транспортироваться в блок бетонирования без потери своих качеств.

После того, как бетонная смесь была транспортирована в блок бетонирования, она перемещается рабочими внутри блока бетонирования, с целью оптимального его 
заполнения. Средствами распределения смеси внутри блока бетонирования служат лопаты, кельмы, виброуплотнители и виброрейки (обычные рейки). После распределения смеси завершается процесс её транспортирования и начинается другой процесс - окончательная укладка бетонной смеси в блоке бетонирования.

\section{Заключение}

Таким образом, проведен анализ технологий транспортировки товарных бетонных смесей, применяющихся в России. Стоит отметить, что правильно подобранная и грамотно реализованная технология транспортировки бетонных смесей в значительной мере определяет качество конечного продукта - возведенного объекта. Но чтобы добиться правильной подборки и грамотной реализации имеющейся технологии, необходимо иметь четкое и структурированное описание самой технологии транспортирования бетонных смесей, что определяет направление дальнейших исследований.

\section{Список информационных источников}

[1] Будихин С.А. Сравнение методов вращения факторов для управления рисками на промышленных предприятиях / А.В. Остроух, А.В. Будихин, С.А. Будихин // Приборы и системы. Управление, контроль, диагностика. - М.: «Научтехлитиздат», 2008. - №10. - С. 60-63.

[2] Джха Прабхакар, Джха Пунам. Создание автоматизированной системы контроля и управления качеством в производстве сборного железобетона // Автоматизация и управление в технических системах. - 2012. - № 1. - С. 44-55.

[3] Жарков Н.Н. Методы построения корпоративной информационной системы управления ресурсами строительного предприятия / Н.Н. Жарков, Т.В. Дорохина А.В. Остроух, Н.Е. Суркова // Вестник Российского нового университета. Серия естествознание, математика, информатика. - М.: РосНОУ, 2004. - Вып. 4. - С. 110113.

[4] Кузнецов И.А. Особенности реализации автоматизированной информационноаналитической системы центра планирования перевозок строительных грузов / И.А. Кузнецов, А.В. Остроух // Вестник МАДИ(ГТУ). - 2008. - Вып. 1(12). - С. 9296.

[5] Куфтинова Н.Г. Процессно-ориентированный подход к автоматизации планирования и управления транспортировкой продукции предприятий промышленности / А.В. Остроух, Н.Г. Куфтинова // Вестник МАДИ - 2010. - Вып. 4(23). - С. 62-66.

[6] Николаев А.Б. Информационные технологии в менеджменте и транспортной логистике: учебное пособие / А.Б. Николаев, А.В. Остроух. - Saint-Louis, MO, USA: Publishing House Science and Innovation Center, 2013. - 254 c. - ISBN 978-0615-67110-9.

[7] Остроух А.В. Автоматизация распределения транспортных средств и техники по объектам строительства с учетом организационных и технических факторов / A.B. 
Остроух, Н.Е.Суркова // Приборы и системы. Управление, контроль, диагностика. - М.: «Научтехлитиздат», 2004. - №12. - С. 6-9.

[8] Остроух А.В. Автоматизация и моделирование работы предприятий по строительству промышленных объектов: дис. ... д-ра техн. наук: 05.13.06: защищена 07.04.09: утв. 19.06.09. - М., 2009. - 357 с.

[9] Остроух А.В. Автоматизация и моделирование работы предприятий по строительству промышленных объектов: автореф. дис. ... д-ра техн. наук: 05.13.06. - М., 2009. - 43 c.

[10] Остроух, А.В. Информационные технологии в научной и производственной деятельности / [ред. А.В. Остроух] - М: ООО "Техполиграфцентр", 2011. - 240 с. ISBN 978-5-94385-056-1.

[11] Остроух А.В. Автоматизация управления строительным предприятием / А.В. Остроух // Приборы и системы. Управление, контроль, диагностика. - М.: «Научтехлитиздат», 2004. - №8. - С. 58-61.

[12] Остроух А.В., Башмаков И.А. Процессная модель технологии транспортировки бетонных смесей автомобильным транспортом // Автоматизация и управление в технических системах. - 2013. - № 4.1. - C. 75-81. DOI: 10.12731/2306-1561-20134-14.

[13] Остроух А.В., Джха Прабхакар Автоматизированная система управления складом железобетонных изделий // Автоматизация и управление в технических системах. - 2013. - № 4.1. - C. 51-56. DOI: 10.12731/2306-1561-2013-4-9.

[14] Ostroukh A.V. Workflow automatization in preparation for building / A.V. Ostroukh, D.S. Tarasenko, D.I. Podporin, N.E. Surkova // Information and Telecommunication Technologies in Intelligent Systems: Proceeding of Fourth International Conference. May 27 - June 03, 2006, Catalina, Italy. pp. 102-104. 